\title{
PENGARUH PEMBERIAN INSENTIF TERHADAP KINERJA KARYAWAN DI PT. SICPA PERURI SECURINK
}

\author{
Ade Sofyan \\ Alumni S-2 MM STIE Trianandra Jakarta \\ Dosen Tetap STIMIK Kharisma - Karawang \\ Prodi D3 - Manajemen Informatika
}

\begin{abstract}
ABSTRAKSI
Penelitian ini bertujuan untuk mengetahui dan menganalisis kinerja karyawan di PT. Sicpa Peruri Securink. Sehubungan dengan hal tersebut bagaimana karyawan dapat bekerja dengan sebaik mungkin dan karyawan mempunyai motivasi yang tinggi dalam menyelesaikan pekerjaan dengan adanya pemberian insentif. Maka terhadap hal tersebut, penelitian ini bertujuan untuk menunjukkan signifikansi pengaruh insentif terhadap kinerja karyawan.

Dalam menganalisa data digunakan analisis deskriptif yang berisi distribusi item dari masing-masing variabel, kemudian analisis regresi linier sederhana dan pengujian hipotesis. Dari hasil pengujian dengan regresi linier sederhana dan analisis regresi parsial menunjukkan bahwa simultan variabel insentif (X) terhadap kinerja karyawan (Y) yang ditunjukkan oleh nilai $\mathrm{R}$ Square yaitu sebesar 0,266. Angka ini menunjukkan bahwa simultan variabel insentif (X) yang digunakan dalam persamaan regresi ini memberikan kontribusi terhadap kinerja karyawan (Y) $26,6 \%$ sedangkan sisanya $73,4 \%$ dipengaruhi oleh variabel lain seperti kepemimpinan dan lainnya.
\end{abstract}

Berdasarkan hasil penelitian ini disimpulkan bahwa insentif berpengaruh signifikan dan positif secara parsial terhadap kinerja karyawan di PT. Sicpa Peruri Securink.

Kata Kunci : Insentif dan Kinerja karyawan

\section{Latar Belakang}

Manajemen sumber daya manusia merupakan satu bidang manajemen yang khusus mempelajari hubungan dan peranan manusia dalam organisasi. Hal ini disebabkan manajemen sumber daya manusia mengatur tenaga kerja yang ada di dalam organisasi, sehingga terwujud tujuan organisasi dan kepuasan kerja karyawan. Manajemen sumber daya manusia juga dapat menghasilkan kinerja yang baik dalam sebuah perusahaan dengan cara penilaian, pemberian balas jasa dalam setiap individu anggota organisasi sesuai dengan kemampuan kerjanya.

Menurut Handoko (2001:155) mengemukakan bahwa Kompensasi adalah " segala sesuatu yang diterima para karyawan sebagai balas jasa untuk kerja mereka.” 
Kompensasi juga merupakan penghargaan yang diberikan karyawan baik langsung maupun tidak langsung, financial maupun non financial yang adil kepada karyawan atas kinerja mereka dalam mencapai tujuan organisasi, sehingga pemberian kompensasi sangat dibutuhkan oleh perusahaan manapun guna meningkatkan kinerja karyawannya. Adapun bentuk kompensasi financial adalah gaji, tunjangan, bonus (insentif), dan komisi. Sedangkan untuk kompensasi nonfinancial diantaranya pelatihan, wewenang dan tanggung jawab, penghargaan atas kinerja serta lingkungan kerja yang mendukung. Jadi untuk mendapatkan kompensasi yang sesuai dengan kinerja karyawan maka dibutuhkan pula karyawan - karyawan yang memiliki potensi yang baik guna tercapainya tujuan bersama. Oleh karena itu di dalam sebuah kompensasi terdapat beberapa kompensasi berupa kompensasi financial yaitu insentif. Dalam pencapaian guna memenuhi kebutuhannya maka karyawan harus memiliki kinerja yang baik agar tercapainya tujuan bersama.

Pemberian insentif merupakan salah satu hal pokok yang harus diperhatikan oleh perusahaan. Semangat tidaknya karyawan bisa juga disebabkan oleh besar kecilnya insentif yang diterima. Apabila karyawan tidak mendapatkan insentif yang sesuai dengan besarnya pengorbanan dalam bekerja, maka karyawan tersebut cenderung malas bekerja dan tidak bersemangat yang ada akhirnya mereka bekerja semaunya tanpa ada motivasi yang tinggi.

Kombinasi keunggulan di bidang produksi, distribusi dan pemasaran, SDM dan teknologi menjadikan PT. PT. Sicpa Peruri Securink Karawang sebagai pemain terdepan dalam industri pupuk nasional. Hal inilah yang menjadikan salah satu daya tarik yang terlihat dari setiap bidang secara menyeluruh pada bidang - bidang tertentu seperti bidang produksi, distribusi dan pemasaran, SDM dan teknologi secara menyeluruh mendapatkan insentif sesuai jabatannya. PT. Sicpa Peruri Securink Karawang memberikan insentif kepada setiap karyawan baik pada bidang manapun secara menyeluruh atau dapat dikatakan meng-global namun pembagian dilihat dari jabatan - jabatan yang di pegang dari setiap karyawan. sistem Pembagian insentif menggunakan sistem pembagian keuntungan dimana pembagian persentase yang dihasilkan tiap tahun kepada karyawan dan sejumlah keuntungan yang di dapat dari penjualan itulah di bagikan perjabatan misalnya saja keuntungan mencapai 50\% maka insentif yang diberikan kepada karyawan perbidang sesuai jabatan dibagi secara merata sejumlah karyawan yang bekerja di PT. Sicpa Peruri Securink Karawang sesuai jabatan. Apabila jabatan yang dipegang oleh seorang karyawan itu tinggi maka insentif yang diterima juga besar sehingga mereka termotivasi dengan adanya 
insentif ini, maka mereka akan lebih semangat lagi dalam mengolah kinerja mereka dengan melakukan yang terbaik sehingga mereka bisa bekerja dengan baik lagi. Dibawah ini table besaran insentif gol jabatan.

Daftar Insentif PT.Sicpa Peruri Securink Karawang

\begin{tabular}{|c|c|c|c|}
\hline Kepangkatan & Sub. GOL & Jumlah orang & Besar Insentif \\
\hline UTAMA SENIOR & F4 & 1 & Rp. 4.276 .000 \\
\hline PIMPINAN UTAMA & F3 & 1 & Rp. 3.669.000 \\
\hline PIMPINAN UTAMA-1 & F2 & 1 & Rp. 3.180.000 \\
\hline PIMPINAN UTAMA-2 & F1 & 5 & Rp. 2.754 .000 \\
\hline PIMPINAN MADYA-1 & E4 & 7 & Rp. 2.409 .000 \\
\hline PIMPINAN MADYA-2 & E3 & 7 & Rp. 20.89.000 \\
\hline PIMPINAN MADYA-3 & E2 & 14 & Rp. 1.810 .000 \\
\hline PIMPINAN MADYA-4 & E1 & 23 & Rp. 1.568 .000 \\
\hline PIMPINAN MUDA-1 & D2 & 52 & Rp. 1.372 .000 \\
\hline PIMPINAN MUDA-2 & D1 & 26 & Rp. 1.190 .000 \\
\hline PELAKSANA UTAMA-1 & $\mathrm{C} 2$ & 13 & Rp. 1.000 .000 \\
\hline PELAKSANA UTAMA-2 & $\mathrm{C} 1$ & 22 & Rp. 865.000 \\
\hline PELAKSANA MADYA-1 & B3 & 15 & Rp. 751.000 \\
\hline PELAKSANA MADYA-2 & B2 & 5 & Rp. 651.000 \\
\hline PELAKSANA MADYA-3 & B1 & 5 & Rp. 564.000 \\
\hline PELAKSANA MUDA-1 & A4 & 9 & Rp. 488.000 \\
\hline PELAKSANA MUDA-2 & A3 & 14 & Rp. 424.000 \\
\hline PELAKSANA MUDA-3 & A2 & 5 & Rp. 364.000 \\
\hline Jumlah & & 225 & Rp. 29.424 .000 \\
\hline
\end{tabular}

Sumber : PT.Sicpa Peruri Securink Karawang (2012-2014)

Begitu juga dengan pimpinan utama-2 pada golongan F1 jumlah orang yang bekerja ada 5 orang dan insentif yang diberikan sebesar Rp. 2.754.000,-. Pimpinan madya-1 golongan E4 jumlah orang yang bekerja sebesar 7 orang besar insentif yang diberikan Rp. 2.409.000,-. Pimpinan madya-2 pada golongan E3 jumlah orang yang bekerja adalah 7 orang besar insentif yang diberikan Rp. 20.89.000,-.pimpinan madya-3 pada golongan E2 jumlah orang yang bekerja adalah 14 orang besar insentif yang diberikan adlah Rp. 1.810.000,-. Pimpinan madya-4 pada golongan E1 jumlah orang yang bekerja pada bagian itu adalah 23 orang insentif yang diberikan Rp. 1.568.000,-.pimpinan muda-1 golongan D2 jumlah orang yang bekerja 52 orang besar insentif yang diberikan Rp. 1.372.000,-. Pimpinan muda-2 pada golongan D1 jumlah orang yang bekerja pada bagian itu ada 26 orang dan besar insentif yang diberikan Rp. 1.190.000,-. Pelaksana utama-1 pada golongan C2 jumlah orang yang bekerja ada 13 orang dan besar insentif yang diberikan Rp. 1.000.000,-. Pelaksana utama-2 pada golongan C1 ada 22 orang yang bekerja 
sedangkan insentif yang diberikan sebesar Rp. 865.000,-. Pelaksana madya-1 pada golongan B3 jumlah yang bekerja ada 15 orang besar insentif yang diberika sebesarRp. 751.000,-. Pelaksana madya02 pada golongan B2 jumlah orang yang bekerja ada 5 orang dan besar insenifyang diberikan Rp. 651.000,-. Pelaksana madya-3 pada golongan B1 jumlah orang yang bekerja ada 5 orang besar insentif yang diberikan Rp. 564.000,-. Pelaksana muda-1 golongan A4 jumlah orang bekerja 9 orang besar insentif Rp. 488.000,-. Pelaksana muda-2 golongan A3 jumlah orang yang bekerja ada 14 orang besar insentif yang diberikan Rp. 424.000,-. Pelaksana muda-3 pada golongan A2 jumlah orang yang bekerja 5 orang besar insentif yang diberikan sebesar Rp. 364.000,- jadi jumlah total keseluruhan dari besar insentif perjabatan adalah Rp. 29.424.000,-. PT. Sicpa Peruri Securink menggunakan jenis insetif bonus dimana insentif yang diberikan kepada pegawai yang mampu bekerja sedemikian rupa sehingga tingkat produksi terlampaui. Insentif yang diberikan oleh PT. Sicpa Peruri Securink berdampak ganda dimana di satu sisi insentif agak berdampak pada bagian operasi dan di sisi lain insentif diharapkan dapat mempengaruhi prilaku serta sikap kerja karyawan.

\section{Hasil penilaian kinerja karyawan di departemen penjualan PT.Sicpa Peruri Securink Karawang}

\begin{tabular}{|c|c|}
\hline \multirow{2}{*}{ Hasil penilaian karyawan } & Tahun \\
\cline { 2 - 2 } & $2012-2016$ \\
\hline Istimewa & $36(10,7 \%)$ \\
Baik & $75(35,7 \%)$ \\
Cukup baik & $76(42,8 \%)$ \\
Kurang & $24(7,2 \%)$ \\
Sangat kurang & $14(3,6 \%)$ \\
\hline Jumlah karyawan & $225(100 \%)$ \\
\hline
\end{tabular}

Sumber : Laporan Penilaian Kinerja PT.Sicpa Peruri Securink Karawang .

Tabel diatas jika kebutuhan mereka telah terpenuhi, besar kemungkinan mereka akan bersemangat dalam beraktivitas dan menunjukan kinerja yang baik. Sikap positif 
dapat mendorong karyawan untuk selalu bekerja dengan baik dan maksimal serta menunjukan keinginan baik mereka untuk mewujudkan tujuan perusahaan.

\section{Identifikasi Masalah}

Berdasarkan latar belakang yang telah diuraikan sebelumnya, maka dapat diidentifikasikan permasalahan yang ada sebagai berikut :

1. Menurunnya semangat kerja dalam meningkatkan produtifitas kerjanya.

2. Karyawan cenderung malas sebagai akibat dari kecilnya pendapatan.

3. Karyawan cenderung bekerja semaunya karena rendahnya pendapatan.

4. Dapat menimbulkan ketidakpuasan karyawan dengan pekerjaaan yang dilakukannya.

5. Belum optimal dalam menghasilkan target yang telah ditetapkan oleh manajemen.

\section{Perumusan Masalah}

Berdasarkan latar belakang serta identifikasi di atas, maka rumusan masalah dalam penelitian ini adalah sebagai berikut : Apakah terdapat pengaruh pemberian insentif terhadap kinerja karyawan PT Sicpa Peruri Securink Karawang?

\section{Tinjauan Teori}

\section{Pengertian Insentif}

Insentif sebagai sarana motivasi yang mendorong para pegawai untuk bekerja dengan kemampuan yang optimal, yang dimaksudkan sebagai pendapatan ekstra di luar gaji atau upah yang telah di tentukan. Pemberian insentif dimaksudkan agar dapat memenuhi kebutuhan para pegawai dan keluarga mereka. Istilah sistem insentif pada umumnya digunakan untuk menggambarkan rencana - rencana pembayaran upah yang dikaitkan secara langsung atau tidak langsung dengan berbagai standar kinerja pegawai atau profitabilitas organisasi.

Insentif dapat dirumuskan sebagai balas jasa yang memadai kepada pegawai yang prestasinya melebihi standar yang telah ditetapkan. Insentif merupakan suatu faktor pendorong bagi pegawai untuk bekerja lebih baik agar kinerja pegawai dapat meningkat.

Dari pengertian di atas untuk lebih jelas tentang insentif, dibawah ini ada beberapa ahli manajemen mengemukakan pengertian mengenai insentif. 
Menurut Hasibuan (2001 : 117) mengemukakan bahwa "Insentif adalah tambahan balas jasa yang diberikan kepada karyawan tertentu yang prestasinya di atas prestasi standar. Insentif ini merupakan alat yang di pergunakan pendukung prinsip adil dalam pemberian kompensasi.

Jadi menurut pendapat - pendapat para ahli di atas dapat disimpulkan, bahwa Insentif adalah dorongan pada seseorang agar mau bekerja dengan baik dan agar lebih dapat mencapai tingkat kinerja yang lebih tinggi sehingga dapat menambah kemauan kerja dan motivasi seorang pegawai agar terciptanya suatu kinerja yang berkualitas sesuai dengan tujuan perusahaan. Jenis jenis insentif dalam suatu perusahaan harus dituangkan secara jelas sehingga dapat di ketahui oleh pegawai dan oleh perusahaan tersebut dapat dijadikan kontribusi yang baik untuk dapat menambah gairah kerja bagi pegawai yang bersangkutan.

Menurut ahli manajemen sumber daya manusia Siagian ( 2002 : 268 ), jenis - jenis insentif tersebut adalah :

1. Piece work, adalah teknik yang digunakan untuk mendorong kinerja pegawai berdasarkan hasil pekerjaan pegawai yang dinyatakan dalam jumlah unit produksi.

2. Bonus, adalah insentif yang diberikan kepada pegawai yang mampu bekerja sedemikian rupa sehingga tingkat produksi yang baku terlampaui.

3. Komisi, adalah bonus yang diterima karena berhasil melaksanakan tugas dan sering diterapkan oleh tenaga - tenaga penjualan.

4. Insentif bagi eksekutif, adalah insentif yang diberikan kepada pegawai khususnya manajer atau pegawai yang memiliki kedudukan tinggi dalam suatu perusahaan, misalnya untuk membayar cicilan rumah, kendaraan bermotor atau biaya pendidikan anak.

5. Kurva Kematangan, adalah insentif yang diberikan kepada tenaga kerja yang karena masa kerja dan golongan pangkat serta gaji tidak bisa mencapai pangkat dan penghasilan yang lebih tinggi lagi, misalnya dalam bentuk penelitian ilmiah atau dalam bentuk beban mangajar yang lebih besar dan sebagainya. Berdasarkan pengertian di atas maka jenis - jenis Insentif adalah : Insentif material, dapat diberikan dalam bentuk :

1. Bonus

2. Komisi

3. Pembagian laba

4. Kompensasi yang ditangguhkan

5. Bantuan hari tua 
Insentif Non-material, dapat diberikan dalam bentuk :

1. Jaminan sosial

2. Pemberian piagam penghargaan

3. Pemberian promosi

4. Pemberian pujian lisan atau tulisan.

Dengan adanya jenis - jenis insentif ini maka perusahaan mampu mendorong motivasi dan gairah kerja pegawai, sehingga pegawai akan terus menjaga dan meningkatkan hasil kerjanya dan pada akhirnya pula akan meningkatkan keuntungan tersendiri dalam pencapaian tujuan yang telah ditetapkan.

\section{Pengertian Kinerja}

Kinerja bagian produktivitas kerja, produktivitas berasal dari kata " Produktif " Artinya sesuatu yang mengandung potensi untuk digali, sehingga produktivitas dapatlah dikatakan sesuatu proses kegiatan yang terstruktur guna menggali potensi yang ada dalam sebuah komoditi atau objek. Filosofi produktivitas sebenarnya dapat mengandung arti keinginan dan udaha dari setiap manusia ( individu maupun kelompok) untuk selalu meningkatkan mutu kehidupan dan penghidupannya.

Agar dapat lebih jelas lagi dalam penjelasan mengenai kinerja berikut ini ada beberapa pengertian kinerja menurut para ahli. Menurut Mangkunegara (2001 : 67) mengemukakan bahwa " hasil kinerja secara kualitas dan kuantitas yang dicapai oleh seseorang pegawai dalam melaksanaka tugasnya sesuai dengan tanggung jawab yang diberikan kepadanya. Jadi menurut pendapat para ahli di atas dapat disimpulkan bahwa kinerja mempunyai hubungan erat dengan masalah produktivitas karena merupakan indikator dalam penentuan bagaimana usaha untuk mencapai tingkat produktivitas yang tinggi dalam suatu perusahaan.

\section{Indikator Kinerja}

Ukuran secara kualitatif dan kuantitatif yang menunjukkan tingkatan pencapaian suatu sasaran atau tujuan yang telah ditetapkan adalah merupakan sesuatu yang dapat dihitung serta digunakan sebagai dasar untuk menilai atau melihat bahwa kinerja setiap hari dalam perusahaan dan perseorangan terus mengalami peningkatan sesuai dengan rencana yang telah ditetapkan.

30.

Jurnal Manajemen \& Bisnis Kreatif 
Menurut Mathis (2002: 78) kinerja karyawan adalah yang mempengaruhi seberapa banyak mereka memberikan kontribusi kepada organisasi antara lain termasuk:

1. Kuantitas kerja, Standar ini dilakukan dengan cara membandingkan antara besarnya volume kerja yang seharusnya (standar kerja normal) dengan kemampuan sebenarnya.

2. Kualitas kerja, Standar ini lebih menekankan pada mutu kerja yang dihasilkan dibanding volume kerja.

3. Pemanfaatan waktu, Yaitu penggunaan masa kerja yang disesuaikan dengan kebijaksanaan perusahaan.

Berdasarkan keseluruhan definisi diatas dapat dilihat bahwa kinerja karyawan merupakan output dari penggabungan faktor-faktor yang penting yakni kemampuan dan minat, penerimaan seorang pekerja atas penjelasan delegasi tugas dan peran serta tingkat seorang pekerja atas penjelasan delegasi tugas. Semakin tinggi faktor-faktor diatas, maka semakin besarlah kinerja karyawan yang bersangkutan.

\section{Faktor-Faktor Yang Mempengaruhi Kinerja}

Menurut Mathis dan Jackson (2001: 82) faktor-faktor yang memengaruhi kinerja individu tenaga kerja, yaitu: 1.Kemampuan mereka, 2.Motivasi, 3.Dukungan yang diterima, 4.Keberadaan pekerjaan yang mereka lakukan, dan 5.Hubungan mereka dengan organisasi.

Selanjutnya menurut Mc. Clelland, mengemukakan 6 karakteristik dari seseorang yang memiliki motif yang tinggi yaitu : 1) Memiliki tanggung jawab yang tinggi 2) Berani mengambil risiko 3) Memiliki tujuan yang realistis 4) Memiliki rencana kerja yang menyeluruh dan berjuang untuk merealisasi tujuan. 5) Memanfaatkan umpan balik yang kongkrit dalam seluruh kegiatan kerja yang dilakukan 6) Mencari kesempatan untuk merealisasikan rencana yang telah diprogamkan Menurut Gibson (1987) ada 3 faktor yang berpengaruh terhadap kinerja : 1) Faktor individu : kemampuan, ketrampilan, latar belakang keluarga, pengalaman kerja, tingkat sosial dan demografi seseorang. 2) Faktor psikologis : persepsi, peran, sikap, kepribadian, motivasi dan kepuasan kerja 3) Faktor organisasi : struktur organisasi, desain pekerjaan, kepemimpinan, sistem penghargaan (reward system).

31.

Jurnal Manajemen \& Bisnis Kreatif 


\section{Indikator Kinerja}

Ukuran secara kualitatif dan kuantitatif yang menunjukkan tingkatan pencapaian suatu sasaran atau tujuan yang telah ditetapkan adalah merupakan sesuatu yang dapat dihitung serta digunakan sebagai dasar untuk menilai atau melihat bahwa kinerja setiap hari dalam perusahaan dan perseorangan terus mengalami peningkatan sesuai dengan rencana yang telah ditetapkan.

Menurut Mathis (2002: 78) kinerja karyawan adalah yang mempengaruhi seberapa banyak mereka memberikan kontribusi kepada organisasi antara lain termasuk:

1. Kuantitas kerja, Standar ini dilakukan dengan cara membandingkan antara besarnya volume kerja yang seharusnya (standar kerja normal) dengan kemampuan sebenarnya.

2. Kualitas kerja, Standar ini lebih menekankan pada mutu kerja yang dihasilkan dibanding volume kerja.

3. Pemanfaatan waktu, Yaitu penggunaan masa kerja yang disesuaikan dengan kebijaksanaan perusahaan.

Berdasarkan keseluruhan definisi diatas dapat dilihat bahwa kinerja karyawan merupakan output dari penggabungan faktor-faktor yang penting yakni kemampuan dan minat, penerimaan seorang pekerja atas penjelasan delegasi tugas dan peran serta tingkat seorang pekerja atas penjelasan delegasi tugas. Semakin tinggi faktor-faktor diatas, maka semakin besarlah kinerja karyawan yang bersangkutan.

\section{Kerangka Konseptual}

\begin{tabular}{|l|l|}
\hline \multicolumn{1}{|c|}{ Insentif (X) } \\
$\begin{array}{ll}\text { a. Bonus } \\
\text { b. Komisi } \\
\text { c. Pembagian Laba } \\
\text { sumber : Malthis (2002). }\end{array}$ & \begin{tabular}{l}
\multicolumn{1}{c|}{ Kinerja (Y) } \\
a. Kualitas kerja \\
b. Kuantitas kerja \\
c. Pemanfaatan waktu \\
sumber : Nasution (2004), Gunawan (2004),
\end{tabular} \\
\hline
\end{tabular}

\subsection{Hipotesis}

\section{Definisi Operasional Variabel}




\begin{tabular}{|c|c|c|c|}
\hline $\begin{array}{c}\text { Variabel } \\
\text { penelitian }\end{array}$ & Definisi & Indikator & Skala \\
\hline Insentif ( x ) & $\begin{array}{l}\text { Insentif adalah suatu bentuk } \\
\text { motivasi yang dinyatakan dalam } \\
\text { bentuk uang atas dasar kinerja } \\
\text { yang tinggi dan juga merupakan } \\
\text { rasa pengakuan dari pihak } \\
\text { organisasi terhadap kinerja } \\
\text { karyawan dan kontribusi } \\
\text { terhadap organisasi ( perusahaan } \\
\text { ). }\end{array}$ & $\begin{array}{l}\text { Bonus } \\
\text { Komisi } \\
\text { Pembagian laba }\end{array}$ & $\begin{array}{l}\text { Ordinal } \\
\text { Ordinal } \\
\text { Ordinal }\end{array}$ \\
\hline Kinerja ( y ) & $\begin{array}{l}\text { Kinerja adalah unjuk kerja yang } \\
\text { merupakan hasil kerja dihasilkan } \\
\text { oleh pegawai atau prilaku nyata } \\
\text { yang ditampilkan sesuai dengan } \\
\text { perannya dalam organisasi }\end{array}$ & $\begin{array}{l}\text { Kualitas kerja } \\
\text { Kuantitas kerja } \\
\text { Pemanfaatan waktu }\end{array}$ & $\begin{array}{l}\text { Ordinal } \\
\text { Ordinal } \\
\text { Ordinal }\end{array}$ \\
\hline
\end{tabular}

\section{Profil Responden}

Sebanyak 69 kuesioner disebarkan kepada responden, responden dalam penelitian ini adalah pegawai PT. Sicpa Peruri Securink Karawang. berikut ini gambaran tentang profil pegawai PT. Sicpa Peruri Securink Karawang gambaran ini di- klasifikasikan berdasarkan jenis kelamin responden, status pendidikan, jabatan usia responden dan lama bekerja responden. Profil pegawai PT.Sicpa Peruri Securink Karawang dapat dilihat dari tabel berikut ini:

\section{Jenis Kelamin Responden}

\begin{tabular}{|c|l|c|c|}
\hline No. & \multicolumn{1}{|c|}{ Jenis Kelamin } & Jumlah & Persentase \\
\hline 1 & Laki - Laki & 40 & 60 \\
2 & Perempuan & 29 & 40 \\
\hline \multicolumn{2}{|c|}{ Total } & 69 & 100 \\
\hline
\end{tabular}

Berdasarkan tabel di atas dapat dilihat bahwa sebanyak 40 orang atau $60 \%$ responden berjenis kelamin Laki - laki.

Sedangkan sebanyak 29 orang atau $40 \%$ responden adalah perempuan. 


\section{Pendidikan Responden}

\begin{tabular}{|c|lc|c|c|}
\hline No. & Pendidikan & Jumlah & Persentase \\
\hline 1. & SMA & & 14 & 25 \\
2. & D3 & & 14 & 25 \\
3. & S1 & & 38 & 40 \\
4. & S2 & & 3 & 10 \\
\hline \multicolumn{2}{r|}{ Total } & 69 & 100 \\
\hline
\end{tabular}

Berdasarkan tabel diatas pendidikan responden pendidikan SMA sebanyak 14 orang atau 25\% dari responden, pendidikan D3 sebanyak 14 orang atau 25\% dari responden, pendidikan S1 sebanyak 38 orang atau 40\% dari responden dan pendidikan S2 sebanyak 3 orang atau 10\% dari responden.

\section{Jabatan Responden}

\begin{tabular}{|c|l|c|c|}
\hline No. & \multicolumn{1}{|c|}{ Jabatan } & Jumlah & Persentase \\
\hline 1. & Staff & 66 & 80 \\
2. & Staff Manager & 2 & 15 \\
3. & Pimpinan Madya 1 & 1 & 5 \\
\hline \multicolumn{2}{|r|}{ Total } & 69 & 100 \\
\hline
\end{tabular}

Berdasarkan tabel diatas dapat melihat jabatan para responden yaitu pada bagian Staff terdapat 66 orang atau 80\% responden sedangkan pada Staff Manager terdapat 2 orang atau 15\% responden dan pada pimpinan madya 1 terdapat 1 orang atau $5 \%$ responden. 


\section{Berdasarkan Usia Responden}

\begin{tabular}{|c|c|c|}
\hline Usia ( Tahun ) & Jumlah & Persentase \\
\hline $20-25$ & 10 & 10 \\
$26-30$ & 14 & 15 \\
$31-35$ & 9 & 5 \\
$>35$ & 36 & 70 \\
\hline Total & 69 & 100 \\
\hline
\end{tabular}

Berdasarkan tabel diatas dapat melihat usia para responden yaitu pada usia 20 - 25 tahun terdapat 10 orang atau $10 \%$ responden, sedangkan pada usia 26 - 30 tahun terdapat 14 orang atau $15 \%$ responden , 31 - 35 tahun terdapat 9 orang atau 5\% responden dan pada usia > 35 tahun terdapat 36 orang atau $70 \%$ responden.

\section{Berdasarkan Lama Bekerja}

\begin{tabular}{|c|c|c|}
\hline Lama bekerja (tahun) & Jumlah & Persentase \\
\hline 5 & 26 & 25 \\
$6-10$ & 4 & 5 \\
$11-15$ & 5 & 9 \\
$>15$ & 34 & 61 \\
\hline Total & 69 & 100 \\
\hline
\end{tabular}

Berdasarkan tabel 4.5 di atas kita bisa melihat lama berja responden yaitu $<5$ Tahun terdapat 26 orang atau $24 \%$ responden, $6-10$ tahun terdapat 4 orang atau 5\% responden sedangkan $11-15$ tahun terdapat 5 orang atau 9\% responden dan pada > 15 Tahun terdapat 34 orang atau $61 \%$ responden. 


\section{Statistics Deskriptif Responden}

\begin{tabular}{|l|r|r|r|r|r|}
\hline & kelamin & usia & pendidikan & lamakerja & \multicolumn{2}{c|}{$\begin{array}{c}\text { Jabatanrespond } \\
\text { en }\end{array}$} \\
\hline $\mathrm{N} \quad$ Valid & 69 & 69 & 69 & 69 & 69 \\
\multicolumn{1}{r|}{ Missing } & 0 & 0 & 0 & 0 & 0 \\
Mean & 1.4348 & 3.0725 & 2.4058 & 2.7971 & 1.0580 \\
Median & 1.0000 & 4.0000 & 3.0000 & 4.0000 & 1.0000 \\
Std. Deviation & .49936 & 1.17972 & .84573 & 1.37819 & .29125 \\
Minimum & 1.00 & 1.00 & 1.00 & 1.00 & 1.00 \\
Maximum & 2.00 & 4.00 & 4.00 & 4.00 & 3.00 \\
Sum & 99.00 & 212.00 & 166.00 & 193.00 & 73.00 \\
\hline
\end{tabular}

\section{Analisis Koefisien Keberartian Persamaan Regresi Linier Sederhana}

\begin{tabular}{|c|c|c|c|c|c|}
\hline \multirow[b]{2}{*}{ Model } & \multicolumn{2}{|c|}{ Unstandardized Coefficients } & \multirow{2}{*}{$\begin{array}{c}\text { Standardized } \\
\text { Coefficients } \\
\text { Beta }\end{array}$} & \multirow[b]{2}{*}{$\mathrm{t}$} & \multirow[b]{2}{*}{ Sig. } \\
\hline & $\mathrm{B}$ & Std. Error & & & \\
\hline (Constant) & 10,120 & 1,999 & & 5,062 & 0,000 \\
\hline insentiftotal & 0,523 & 0,106 & 0,515 & 4,924 & 0,000 \\
\hline
\end{tabular}

Untuk menetapkan rumusan persamaan regresi sederhana pengaruh pemberian insentif terhadap kinerja karyawan PT.Sicpa Peruri Securink Karawang dilakukan analisis koefisien regresi. Hasilnya adalah sebagai berikut : konstanta regresi : 10,120, koefisien regresi variabel insentif ( X ) : 0,523. Berdasarkan hasil analisis koefisien regresi di atas, maka rumus persamaan regresi linier sederhana adalah : $\quad \mathrm{Y}=10,120+0,523 \mathrm{X}+\mathrm{e}$.

Persamaan regresi linier sederhana ini dapat diartikan sebagai berikut :

a. Nilai konstanta 10,120, artinya kinerja karyawan PT.Sicpa Peruri Securink Karawang sebesar 10,120 satuan, dengan ini asumsi insentif dalam keadaan konstan/tetap.

b. Nilai koefisien regresi insentif (X) 0,523, tingkat signifikan uji-t (p-value) sebesar 0,000 (< 0,05). hasil ini membuktikan bahwa kinerja karyawan secara signifikan akan meningkat sebesar 52,3\% jika insentif bagi karyawan PT.Sicpa Peruri Securink Karawang meningkat $1 \%$. 


\section{Hasil Korelasi dan Koefisien Determinasi}

\begin{tabular}{|c|c|c|c|c|c|c|}
\hline \multicolumn{7}{|c|}{ Coefficients $^{a}$} \\
\hline \multirow{2}{*}{\multicolumn{2}{|c|}{ Model }} & \multicolumn{2}{|c|}{ Unstandardized Coefficients } & $\begin{array}{l}\text { Standardized } \\
\text { Coefficients }\end{array}$ & \multirow[b]{2}{*}{$\mathrm{t}$} & \multirow[b]{2}{*}{ Sig. } \\
\hline & & $\mathrm{B}$ & Std. Error & Beta & & \\
\hline \multirow[t]{2}{*}{1} & (Constant) & 10.120 & 1.999 & & 5.062 & .000 \\
\hline & insentiftotal & .523 & .106 & .515 & 4.924 & .000 \\
\hline
\end{tabular}

a. Dependent Variable: kinerjatotal

\section{Uji t (Uji Parsial) untuk Variabel Insentif}

Untuk Uji hipotesis pengaruh X terhadap Y, dapat diinterpretasikan berdasarkan uji probabilitas t-statistik, dengan t-hitung $(4,924)$ dan sig. sebesar 0,000 yang lebih kecil dari 0,05 yang berarti variabel insentif berpengaruh signifikan dan positif terhadap kinerja karyawan di PT. Sicpa Peruri Securink Karawang pada taraf nyata 5\%. Oleh karena itu diambil keputusannya adalah terima H1 dan tolak Ho.

\section{Hasil Uji F (simultan/serempak)}

Korelasi menjelaskan hubungan antara variabel bebas $\mathrm{X}$ yang tersusun dalam model persamaan regresi yaitu insentif berpengaruh positif dan signifikan terhadap kinerja karyawan di PT. Sicpa Peruri Securink Karawang (Y). Sedangkan kooefisien determinasi menjelaskan seberapa besar kontribusi yang diberikan oleh variabel bebas terhadap variabel kinerja karyawan .

\begin{tabular}{|l|r|r|r|r|}
\hline Model & \multicolumn{2}{|c|}{ Model Summary } & \multicolumn{2}{c|}{$\begin{array}{c}\text { Std. Error of the } \\
\text { Estimate }\end{array}$} \\
\hline 1 & $\mathrm{R}$ & R Square & Adjusted R Square & 1.92547 \\
\hline
\end{tabular}

Berdasarkan tabel diatas, koefisien $\mathrm{r}$ sebesar 0,515 berarti variabel bebas memiliki hubungan yang erat dengan kinerja karyawan di PT. Sicpa Peruri Securink Karawang sedangkan $\mathrm{R}^{2}$ (koefisien determinasi) adalah sebesar 0,266 atau 26,6\%. Ini berarti variabel bebas $\mathrm{X}$ dapat menjelaskan kinerja karyawan pada PT. Sicpa Peruri Securink Karawang dengan kontribusi 
sebesar 26,6\% sedangkan 73,4\% sisanya dipengaruhi oleh varibel lain seperti kepemimpinan , disiplin dan lainnya.

\begin{tabular}{|ll|r|r|r|r|r|}
\hline \multicolumn{1}{|c|}{ ANOVA $^{\mathrm{b}}$} & & \\
\hline 1 & Sum of Squares & df & Mean Square & F & Sig. \\
\hline & Regression & 89.892 & 1 & 89.892 & 24.246 & $.000^{\mathrm{a}}$ \\
& Residual & 248.398 & 67 & 3.707 & & \\
& Total & 338.290 & 68 & & & \\
\hline
\end{tabular}

a. Predictors: (Constant), insentiftotal

b. Dependent Variable: kinerjatotal

Berdasarkan tabel di atas menunjukkan hasil uji ANOVA atau F Test bahwa hasil $\mathrm{F}$ hitung sebesar 24,246. Hal ini berarti bahwa F hitung lebih besar dari F tabel yaitu 3,98 yang artinya signifikan, dengan tingkat signifikansi 0,000 yang lebih kecil dari $(<0,05)$ berarti insentif berpengaruh positif dan signifikan terhadap kinerja karyawan. Berdasarkan kuesioner yang disebar kepada karyawan di PT.Sicpa Peruri Securink Karawang diketahui untuk variabel bebas (X) insentif dengan item bonus, komisi, dan pembagian laba berpengaruh signifikan dan positif secara parsial terhadap kinerja karyawan di PT.Sicpa Peruri Securink Karawang. Dengan R square sebesar 0,266 (26,6\%) dan persamaan regresi sederhana yaitu $\mathrm{Y}=10,120+0,523 \mathrm{X}$. Adapun juga penelitian terdahulu menyimpulkan hasil penelitiannya bahwa gaji dan insentif berpengaruh signifikan dan positif terhadap produktivitas kerja karyawan . Namun dari hasil penelitian yang saya ambil dengan $\mathrm{R}$ square sebesar 0,266 (26,6\%) sedangkan sisanya adalah $73,4 \%$ dipengaruhi oleh variabel lain seperti kepemimpinan,disiplin,motivasi serta keadilan dalam perusahaan ini.

Mengapa $\mathrm{R}$ square lebih kecil dibandingkan sisanya karena didalam perusahaan ini menggunakan sistem pembagian insentif dengan cara menyeluruh sesuai dengan jabatan jabatan yang mereka pegang padahal di satu sisi lain jenis pekerjaan yang mereka kerjaan sama sehingga adanya ketidakadilan didalam perusahaan pada faktor beban kerja.

\section{Kesimpulan}

Berdasarkan hasil penelitian dan kajian dapat disimpulkan menjadi beberapa hal sebagai berikut. Penelitian ini yang menyatakan bahwa insentif berpengaruh signifikan dan positif secara bersama - sama terhadap kinerja karyaan di PT. Sicpa Peruri Securink Karawang .

\section{Saran}


Dari kesimpulan yang telah diperoleh, maka dapat diberikan saran - saran sebagai berikut:

1. Insentif yang diberikan untuk karyawan harus lebih baik lagi dalam arti sesuai dengan kinerja karyawan itu sendiri dimana suatu pekerjaan haruslah sesuai dengan kemampuan karyawan.

2. Perusahaan hendaknya lebih memperhatikan besarnya pemberian komisi yaitu imbalan yang diberikan berdasarkan pada persentase penjualan, agar hasil kerja karyawan dalam menjual produk dapat dihargai dan mampu meningkatkan loyalitas karyawan terhadap perusahaan.

3. Perusahaan hendaknya lebih memperhatikan beban kerja seseorang dalam memberikan insentif karena dalam penelitian ini bisa dilihat bahwa ada beberapa faktor ketidak adilan dalam penggajian terhadap beban kerja.

4. berdasarkan pada persentase penjualan, agar hasil kerja karyawan dalam menjual produk dapat dihargai dan mampu meningkatkan loyalitas karyawan terhadap perusahaan.

5. Perusahaan hendaknya lebih memperhatikan beban kerja seseorang dalam memberikan insentif karena dalam penelitian ini bisa dilihat bahwa ada beberapa faktor ketidak adilan dalam penggajian terhadap beban kerja.

\section{DAFTAR PUSTAKA}

Aba Yazid, 2009 “ Pengaruh Gaji Dan Iinsentif Terhadap Produktivitas Kerja Karyawan ( Pada CV. Indo Perkasa Computindo Situbondo ).” Skripsi Universitas Islam Negeri (Malang Uin) Maulana Malik Ibrahim. Di akses September 2012.

A.H Puapowarsito,MBA,Ph.D.2008. Metode Penelitian Organisasi Dengan Aplikasi Program SPSS, Bandung, Humaniora.

Dessler, Garry, 2007. Manajemen Sumber Daya Manusia, buku 1 \& 2, Jakarta : Penerbit Indeks.

Ghozali, Imam. 2001. Aplikasi Analisis Multivariate Dengan Program SPSS Badan Penerbit Undip, Semarang .

Handoko,T.Hani,2001,Manajemen Personalia Dan Sumber Daya Manusia (Edisi 2), Yogyakarta : Badan Penerbit Fakultas Ekonomi.

Hasibuan. Melayu S.P 2001. Manajemen Sumber Daya Manusia, Jakarta : PT. Bumi Aksara. Haminati sharikha, Aan permana, 2012. "Pengaruh Pemberian Insentif erhadap Kinerja Pustakawan Di Perpustakaan Daerah Provinsi Jawa Tengah. ’Diakses September 2012. 
Mangkunegara, Prabu. 2002. Manajemen Sumber Daya Manusia Perusahaan, Cetakan ke-2. Bandung : PT. Remaja Rosdakarya Offset.

Mondy,R. Wayne, 2008, Manajemen Sumber Daya Manusia, Buku 1 \& 2, akarta : Penerbit Erlangga.

Primbada, Bangkit , 2012. “Pengaruh Pemberian Insentif Terhadap Kinerja Karyawan ( Studi Pada AJB BUMI PETERA 1921 Kantor Cabang kayutangan, malang)'. Skripsi Diakses September 2012.

Robert L, Malthis \& Jhon H. Lackson 2002. Manajemen Sumber Daya Manusia, (Bisnis, Manajemen, keuangan, dan SDM). Edisi 9. Jakarta :Salemba Siagian, Sondang P. 2002. Kiat Meningkatkan Prestasi Kerja. Jakarta : Rineka Cipta.

Suryani, Devi , 2012." Hubungan Pemberian Insentif Terhadap Kinerja Agen Penjualan Polis Asuransi Pada PT. Asuransi Bintang Tbk Cabang Pekan Baru”. Skripsi Diakses September 2012. 